\title{
The Pallid Sturgeon: Scientific Investigations Help Understand Recovery Needs
}

\author{
By Aaron J. DeLonay
}

Understanding of the pallid sturgeon (Scaphirhynchus albus; fig. 1) has increased significantly since the species was listed as endangered over two decades ago. Since 2005, scientists at the U.S. Geological Survey (USGS) Columbia Environmental Research Center (CERC) have been engaged in an interdisciplinary research program in cooperation with the U.S. Army Corps of Engineers Missouri River Recovery Program, U.S. Fish and Wildlife Service, Nebraska Game and Parks Commission, and numerous other State and Federal cooperators to provide managers and policy makers with the knowledge needed to evaluate recovery options. During that time, the USGS has worked collaboratively with river scientists and managers to develop methods, baseline information, and research approaches that are critical contributions to recovery success.

The pallid sturgeon is endangered throughout the Missouri River because of insufficient reproduction and survival of early life stages. Primary management actions on the Missouri River designed to increase reproductive success and survival have focused on flow regime, channel morphology, and propagation. The CERC research strategies have, therefore, been designed to examine the linkages among flow regime, re-engineered channel morphology, and reproductive success and survival. Specific research objectives include the following: (1) understanding reproductive physiology of pallid sturgeon and relations to environmental conditions; (2) determining movement, habitat use, and reproductive behavior of pallid sturgeon; and (3) quantifying availability and dynamics of aquatic habitats needed by pallid sturgeon for all life stages.

\section{Reproduction and Environmental Cues: How do environmental factors influence reproductive success?}

Pallid sturgeon may live a long time and take many years to reach reproductive maturity. Female pallid sturgeon in the Missouri River may not spawn until they are 10 years old or older, and then they do not spawn every year. Environmental factors that control the frequency and timing of reproduction have a strong influence on the potential of a sturgeon population to recover (Wildhaber and others, 2007). Scientists at the CERC are evaluating the readiness of pallid sturgeon to spawn in hatcheries and the river by using a suite of blood chemistry measurements and histological examinations. These measurements provide an accurate assessment of each fish's reproductive status and nearness to spawning. Results indicate that reproductive readiness and spawning in pallid sturgeon is the result of a complex interaction between internal physiological conditions and environmental factors or "cues" (fig. 2). Day length and temperature appear to be the most important of the cues that trigger reproductive readiness (DeLonay and others, 2009); however, conditions at the spawning site, the presence of other reproductive adults, and the reproductive health of the fish may ultimately play an important role in determining precisely how successful spawning will be and whether eggs will hatch and survive.

Sturgeon species in the Missouri River with intersex, teratogenic tumors, testicular deformities, and egg parasites have been documented by CERC scientists (DeLonay and others, 2009). To date, it is not known what is causing these reproductive abnormalities

Figure 1. Reproductive adult male pallid sturgeon (Scaphirhynchus albus). 
or whether they are influencing sturgeon reproductive success. There is concern that contaminants in water and the food chain may be causing these pathologies. Through laboratory studies in progress at the $\mathrm{CERC}$, researchers are beginning to evaluate whether chemicals measured in the Missouri River at levels of concern for other species may be affecting reproduction in shovelnose (S. platorynchus) and pallid sturgeons.

\section{Migration and Spawning: Are pallid sturgeon spawning successfully in the Missouri River?}

Scientists at the CERC use physiological assessments in conjunction with telemetry tags and advanced microsensors to monitor pallid sturgeon migrations and track pallid sturgeon to their spawning locations. Adult pallid sturgeon are implanted with transmitters and small data storage devices that record temperature and depth. Researchers follow the fish as they move upstream to spawn, thus recording habitats used during migration and at the eventual spawning destination. Results with limited numbers of pallid sturgeon show that females in the Lower Missouri River exhibit spawning behavior characterized by rapid upstream movement, stopping then spawning within hours, followed by a variable intermittent downstream movement (DeLonay and others, 2009) (figs. 2 and 3). Spawning is verified by the recapture of females that have released their eggs after spawning and by observation of spawning aggregations with high-resolution sonar imagery. The CERC studies show that wild and hatchery-origin pallid sturgeon are spawning at multiple locations in the Lower Missouri River, however, it is as yet unknown how many adults are spawning and whether any young are surviving to contribute to the population. Comparisons between adult sturgeon that do spawn and those that do not provide insight into the possible factors that may promote spawning success. Data from these studies provide information that managers may use to facilitate migration or create conditions at spawning sites that are optimal for aggregation of adults, egg deposition, and survival of young.

\section{Habitat Use and Availability: What types of habitats do sturgeon use, and how much is available?}

Hydrologists use advanced sonar and hydroacoustic depth, velocity, and substrate mapping tools to assess habitats where sturgeon are found (fig. 4). Research at the CERC has shown that sturgeon may integrate information at multiple spatial scales when choosing which habitats to occupy or move through. Transitional zones between habitat types and the arrangement of habitat patches and features may be among the more significant factors in determining where sturgeon are found and how they migrate (Reuter and others, 2009). All female pallid sturgeon tracked during reproduction appeared to have spawned in areas of swift, converging flow on outside bends, over or adjacent to gravel and cobble (DeLonay and others, 2009). Hydraulic models developed from these data can

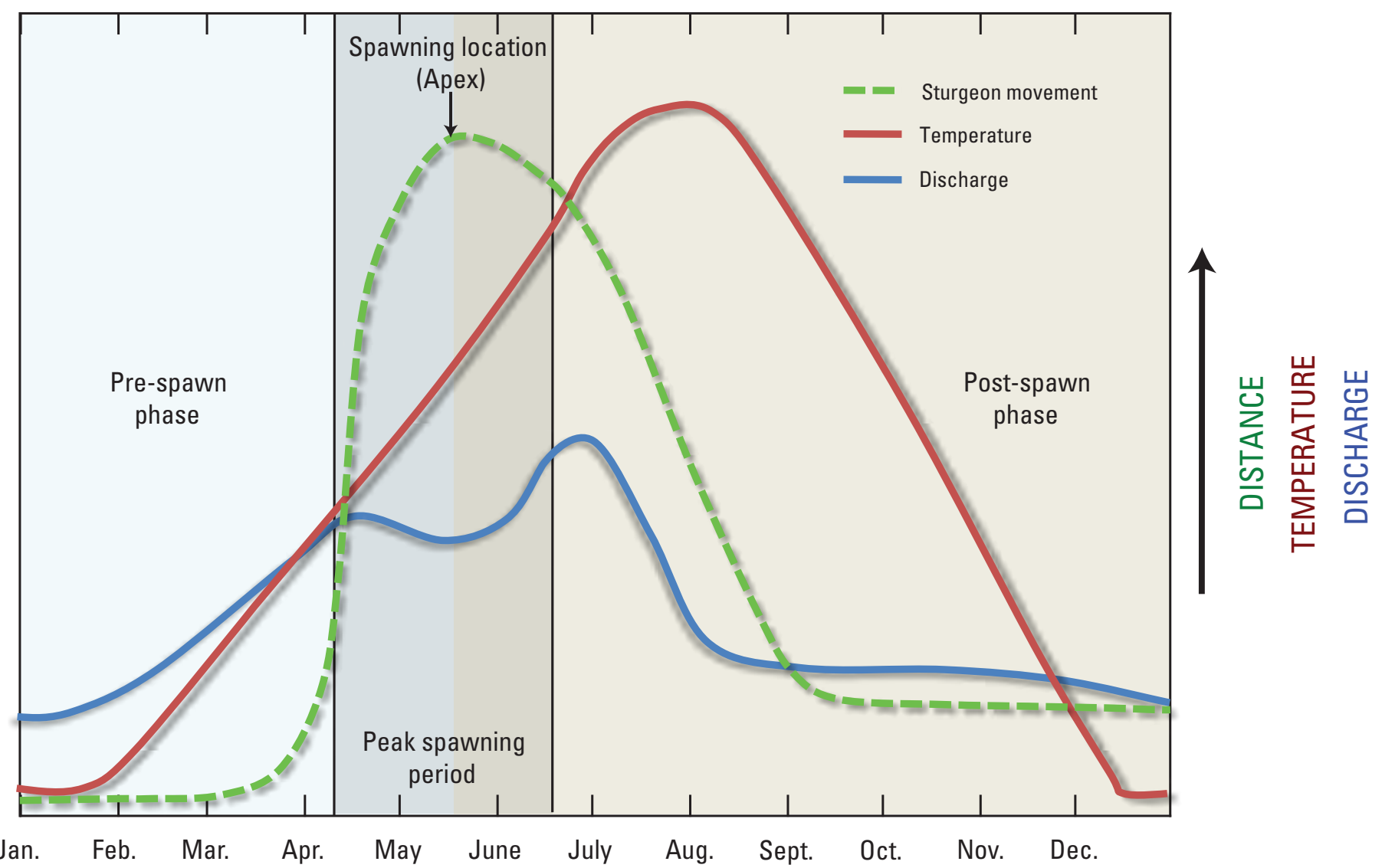

Figure 2. Conceptual model of migration and spawning behavior of female pallid sturgeon (Scaphirhynchus albus). 


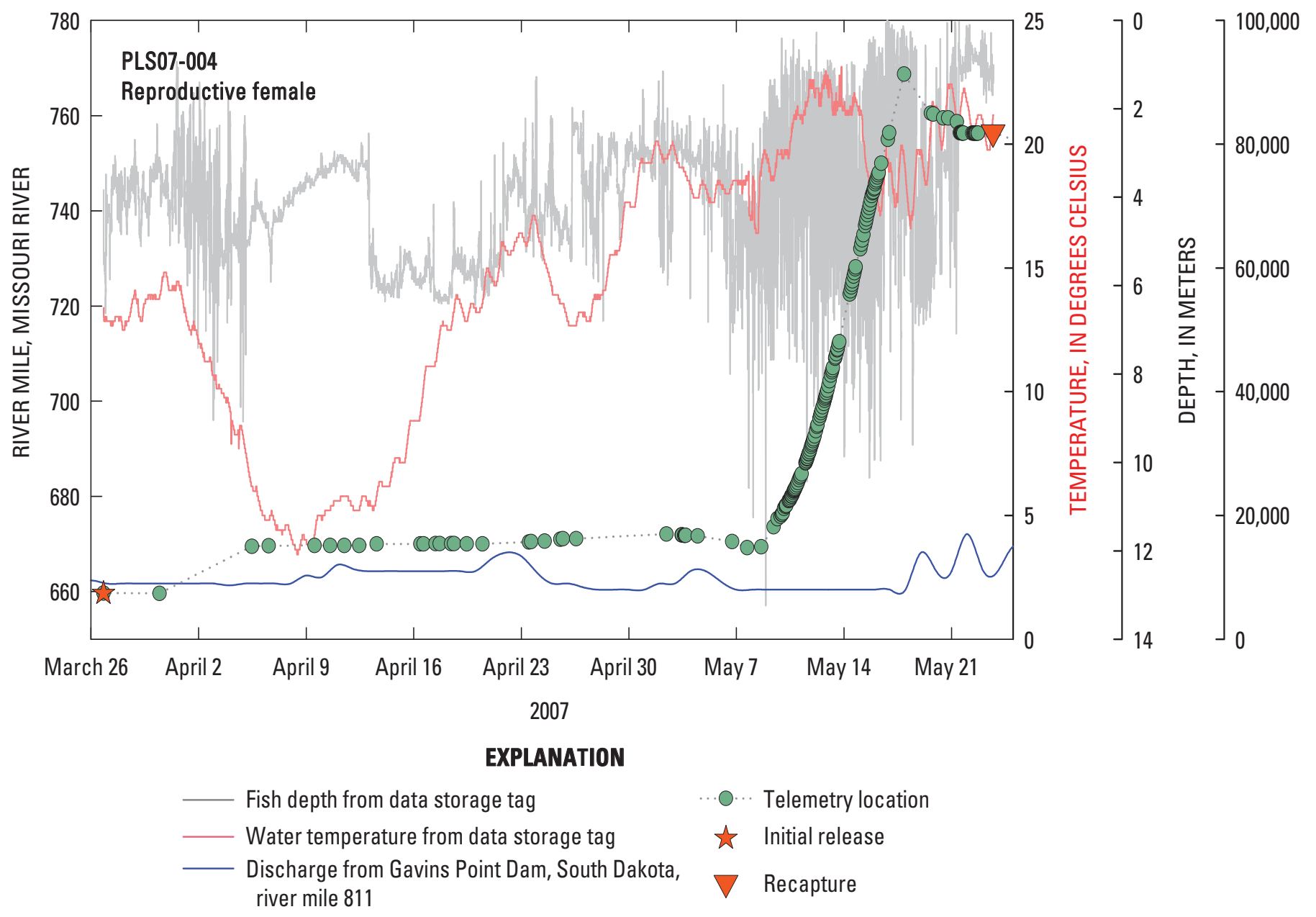

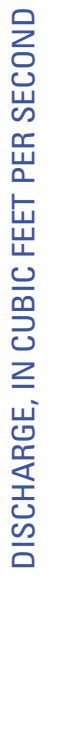

Figure 3. Pallid sturgeon (Scaphirhynchus albus) females in the Missouri River move rapidly upstream to spawn in spring.

be used to quantify how flow and channel morphology alterations combine to change habitats used by sturgeons. These same models also provide insight into larval transport, barriers or pathways for migration, and processes of sediment transport-a critical component of the environmental conditions that create and maintain quality habitat. Managers can use this information to determine if critical habitats are limiting, to assess relative habitat quality, and to evaluate the trade-offs between flow change and channel re-engineering to achieve habitat goals for the pallid sturgeon.

\section{References Cited}

DeLonay, A.J., Jacobson, R.B., Papoulias, D.M., Simpkins, D.G., Wildhaber, M.L., Reuter, J.M., Bonnot, T.W., Chojnacki, K.A., Mestl, G.E., and Mac, M.J., 2009, Ecological requirements for pallid sturgeon reproduction and recruitment in the Lower Missouri River-A research synthesis 2005-08: U.S. Geological Survey Scientific Investigations Report 2009-5201, 59 p. (Also available at http://pubs.usgs.gov/ sir/2009/5201/.
DeLonay, A.J., Papoulias, D.M., Wildhaber, M.L., Mestl, G.E., Everitt, D.W., and Chojnacki, K.A., 2007, Movement, habitat use, and reproductive behavior of shovelnose sturgeon and pallid sturgeon in the Lower Missouri River, in Korschgen, C.E., ed., Factors affecting the reproduction, recruitment, habitat, and population dynamics of Pallid Sturgeon and Shovelnose Sturgeon in the Missouri River: U.S. Geological Survey Open-File Report 2007-1262, p. 23-102.

Reuter, J.M., Jacobson, R.B., Elliott, C.M., and DeLonay, A.J., 2009, Assessment of Lower Missouri River physical aquatic habitat and its use by adult sturgeon (genus Scaphirhynchus) 2005-07: U.S. Geological Survey Scientific Investigations Report 2009-5121, 81 p. (Also available at http://pubs. er.usgs.gov/usgspubs/sir/sir20095121.

Wildhaber, M.L., DeLonay, A.J., Papoulias, D.M., Galat, D.L., Jacobson, R.B., Simpkins, D.G., Braaten, P.J., Korschgen, C.E., and Mac, M.J., 2007, A conceptual life-history model for pallid and shovelnose sturgeon: U.S. Geological Survey Circular 1315, 18 p. (Also available at $h t t p: / / p u b s . e r . u s g s$. gov/circ/2007/1315. 


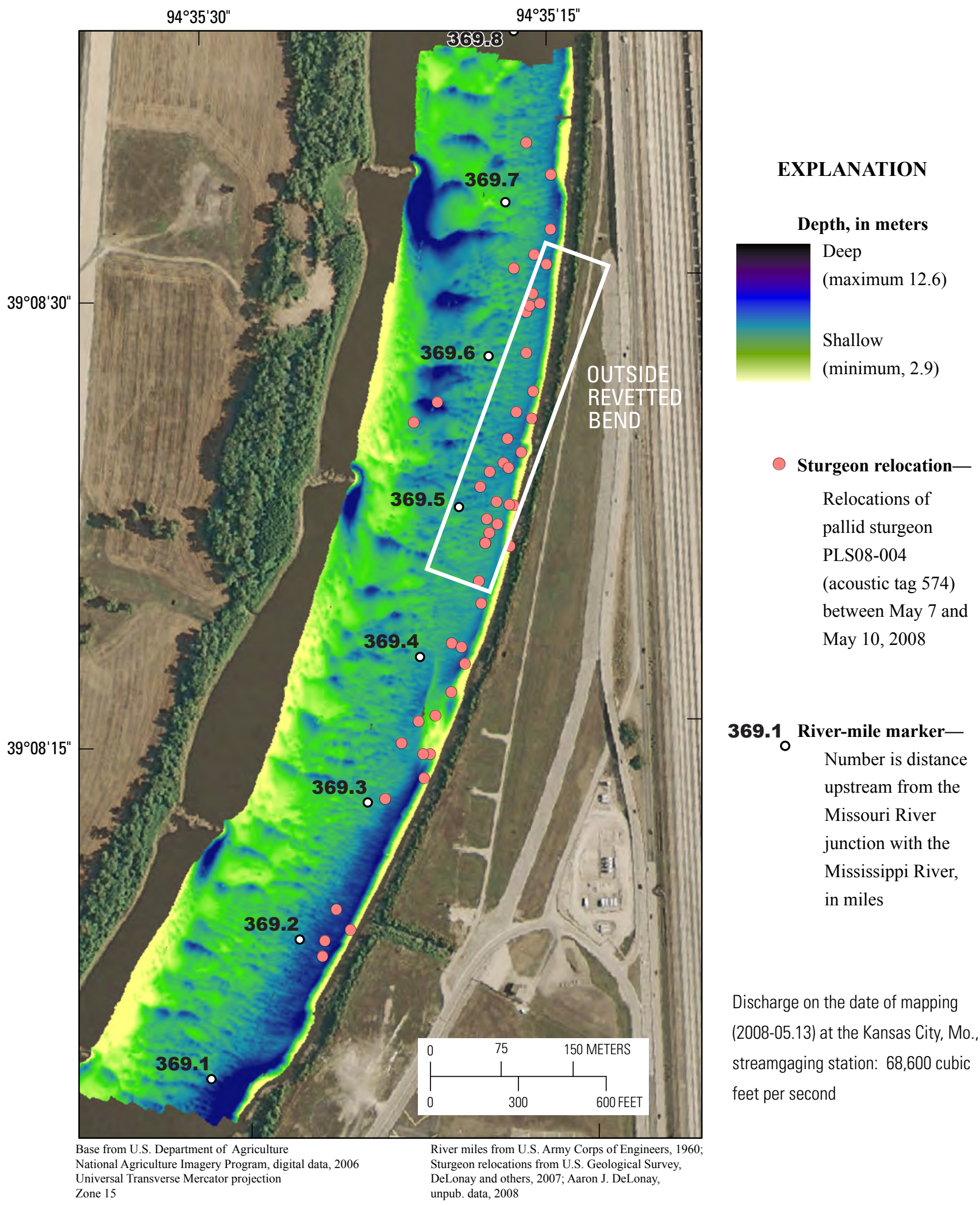

Figure 4. Multibeam bathymetric map showing location of a female pallid sturgeon (Scaphirhynchus albus) during spawning in the Missouri River.

For more information concerning this publication, contact: Director, USGS Columbia Environmental Research Center 4200 New Haven Road

Columbia, MO 65201

(573) 875-5399
Or visit the Columbia Environmental Research Center Web site at: http://www.cerc.usgs.gov/

Publishing support provided by:

Rolla and Lafayette Publishing Service Centers 